\title{
Erken çocukluk döneminde ailelerin evde ücretli bakım hizmetlerine yönelik talepleri
}

\section{Family's demands for paid care services at home in early childhood period}

\author{
Hüseyin Yolcu ${ }^{1}$
}

\begin{abstract}
Makale Geçmişi
Geliş : 01 Mayıs 2019

Düzeltme : 04 Haziran 2019

Kabul : 09 Haziran 2019

Çevrimiçi : 10 Haziran 2019
\end{abstract}

Makale Türü

Arastırma Makalesi
Article History

Received : 01 May 2019

Revised : 04 June 2019

Accepted : 09 June 2019

Online : 10 June 2019

Article Type

Research Article
Öz: Bu araştırmada, ailelerin erken çocukluk eğitimi ve bakımı (EÇBE) döneminde evde ücretli bakım hizmetlerine yönelik talepleri üzerinde belirleyici olan nedenler ve bu süreçte karșılașılan sorunların ortaya konulması amaçlanmıştır. Araştırma tarama modelinde betimsel bir çalışmadır. Araştırmanın çalıșma grubunda 218 aile bulunmaktadır. Veriler araștırmacı tarafından geliștirilen anket yoluyla elde edilmiştir. Verilerin çözümlenmesinde betimsel istatistiklere başvurulmuştur. Ailelerin evde ücretli bakım hizmetlerine talepte bulunmalarındaki nedenlerin başında ebeveynlerin çalışıyor olması, çocuğa bakacak başka kimsenin bulunmaması ve çocuklarının yaşının küçük olması gelmektedir. Güvenilir olma bakıcılarda aranan öncelik bir özellik olarak öne çıkmaktadır. İşe alınacak bakıcıların tanıdık olması tercih edilmektedir. Evde ücretli bakım hizmeti alma sürecinde yaşanılan sorunların başında, bakıcıların zamanında işe gelmemesi yer almaktadır. EÇBE döneminde evde ücretli bakım hizmetinin arz boyutunu oluşturan bakıcı kadınlar üzerinden, onların bu süreçteki algı ve deneyimleri ortaya konulmasını içeren araştırmalar yapılması gerektiği düşünülmektedir.

Anahtar Kelimeler: Talep; Eğitim talebi; Bakıcı; Evde ücretli bakım hizmetleri; Erken çocukluk dönemi

Abstract: This study aims to reveal the determining variables on families' demand and the problems of paid care services in the early childhood period. The study is a descriptive study in scanning model. The study includes 218 families in its research group. The data is obtained via the survey the researcher has developed. Data analysis has been made using descriptive statistical methods. The main contributors to families' paid care services demand are that both parents are working without anyone else to look after their children and their children being infants or toddlers. Trustworthiness comes out as a prominent characteristic that is looked for in a potential caregiver. It is preferred that the caregiver is known or been met beforehand by the hiring family.

Keywords: Demand; Educational demand; Caregiver; Paid at-home care-giving services; Early childhood period 


\section{SUMMARY}

\section{Introduction}

Studies on early childhood care and education (ECCE) demonstrate that facilitation and extentification of ECCE is beneficial for both children and the society in general (Conti and Heckman, 2012; Kağıtçıbaş1, Sunar, Bekman and Cemalcilar, 2005; Kaytaz, 2005; Pinarcioğlu and Çelik, 2015). ECCE is a supporting element to women's employment from the aspects of demand and supply (Anderson and Levin, 1999; ERG and AÇEV, 2016; Kağıtçıbaşı et all., 2005; İlkkaracan, Kim and Kaya, 2015; Staab and Gerhard.2010) For example, De Barros, Olinto, Lunde and Carvalho (2011), demonstrated that free access to ECCE significantly increases women's employment and their participation in the labor market. This rate of increase is $100 \%$ in women who weren't employed before.

Families inevitably face various decisions about childcare and employment right after the point that their children are born (Del Boca, 2015). The first decision the families are to make is whether they are going to provide their children care by themselves or not. There are many factors that affect this decision. If a family is not to handle childcare by their own, they usually tend to seek the child's grandparents' or close relatives' help, which is regarded as the second-best option. In the case of the first two options failing to deliver a result, families usually think of public or private institutional care services. Yet; the problems in sufficient ECCE access, regardless of the provider being public or private, may limit the opting potential of the families (World Bank, 2015a, 2015b, 2016).

The supply-based problems with ECCE can make some families consider a fourth option over the aforementioned three solutions. This fourth option is to seek paid at-home-caregiving services. To put it more throughly, it is the option of hiring a paid babysitter to handle their children's care.

There are existing studies done in Turkey in related literature regarding caregiving services (Baytar, 2014; Dikmen and Kart, 2017; Doğan, 2018; Kakıc1, Emeç and Üçdoğruk, 2007; Koyuncu, 2018; Küçük, 2009; 2009; Suğur, Suğur and Şavran, 2008; Yaman, 2010). Yet, this study directly aims to detect the determining factors on families' paid at-home childcare services demand and the problems they experience, as different from the previous studies on the topic.

\section{Method}

The study is a descriptive study made in the general survey model. The target population of the study consists of families that employ paid at-home caregiving services during the ECCE period in the cities of Ankara and Kastamonu. Yet, it has not been possible to reach a definitive conclusion about the actual size of the target population of the study. Because of this, simple random sampling method was used to provide a target population for the study. The study group consists of 218 families. The data has been obtained by a survey developed by the researcher. The said data have been analyzed with descriptive statistical methods. 


\section{Results}

The most prominent three resaons that contribute to families' demand for paid at-home caregiving services during ECCE are the mother and father both being employed (47,8\%), the child being junior age-wise $(17,0 \%)$ and that the family does not have anyone to look after their children except for the family members $(8,7 \%)$.

The most likely qualities for families to consider in their potential caregiver are the caregiver being trustworthy $(10,6 \%)$, the age of the caregiver $(10,3 \%)$, the references for the caregiver $(9,9 \%)$ and that the caregiver's education level $(9,9 \%)$. The majority of families prefer that the caregiver be someone they know $(33,5 \%)$. Asides from that, families usually hire this type of services for their children aged 0-12.

$58,2 \%$ of families have reported that they have an age limit in their potential hire while $47,2 \%$ reported otherwise. More so, the majority of families prefer that the children be looked after in their own homes.

Only 2,3\% families reported using tracking devices or similar tools while their children are with their caregiver while a $65 \%$ claimed that they make a phone call to check up on them if necessary. The most prominent problem families have with their caregivers is that caregivers not arriving in time to work.

\section{Conclusion and Discussion}

Families demand paid at-home care services for reasons like their family consisting of working parents, family failing in finding somebody else to look after their children and their children's junior age. The fact that a majority of the families that participated in this study hired a caregiver for their children starting from 0-12 months of age also supports this result. In Ceylan's (2019) study, it is observed that families prefer institutional child care services rather than at-home ones in order to support their children's development and education.

The caregiver being trustworthy is the primary qualification that families seek in their search of a caregiver. It can be said that the reason behind families' choice of caregivers they already know over stranger individuals is ruling out the potential risks in the case of choosing a person they do not know at all. The study findings in literature also supports this finding (Dikmen and Kart, 2017; Fidan and Özdemir, 2011). It is expected from caregivers that they not only look after the children but also they make educational acts and help with housework. The formal relationship between the caregiver and family can be transformed into a close and patriarchal, family-like one with time (Suğur, Suğur, and Şavran, 2008). It can be said that generally, families are content with their caregivers and plan to keep them until their children enrolls in school. The biggest problem families experience with their caregiver is that their caregiver not arriving work on time. 


\section{GİRIŞ}

Sosyal bakım hizmet alanının önemli alt alanlarından biri olan erken çocukluk bakım ve eğitimi (EÇBE); çocuğun doğumundan zorunlu eğitime başlama yaşına kadar olan büyüme, gelişme ve bakımla ilgili tüm süreçleri içermektedir. Bu dönemdeki bakım ve eğitim hizmetlerinin niteliğinin, çocukların zihinsel gelişimlerinin yanı sıra, dil becerisi, duyusal denetimi ve kavrama becerisi üzerinde oldukça belirleyici olduğu bilinmektedir (Eğitim Reform Girişim [ERG] ve Anne Çocuk Eğitim Vakfı [AÇEV], 2016). EÇBE ile ilgili olarak yapılan araştırmalar bu hizmetlerin kurumsal olarak sunulması ve yaygınlaştırılmasının hem çocuk hem de toplum açısından yararını ortaya koymaktadır (Conti ve Heckman, 2012; Kağıtçıaşı, Sunar, Bekman ve Cemalcılar, 2005; Kaytaz, 2005; Pınarcıoğlu ve Çelik, 2015; Birleşmiş Milletler Çocuklara Yardım Fonu [UNICEF], 2013). Örneğin, Kağıtçıbaşı ve diğerleri (2005) tarafindan yapılan “Erken Destek Projesi” adlı boylamsal araştırmada elde edilen bulgular burada belirtilenleri doğrulamaktadır. Buna göre, EÇBE'den yararlanan çocukların, böyle bir eğitimi almayan çocuklarla karşılaştırıldı̆̆ında, ortalama eğitim sürelerinin daha fazla olduğu, birçoğunun üniversiteye devam ettiği, yüksek statülü işlerde çalıştığı, çağdaş, sosyal ve ekonomik yaşama katılımlarının da daha yüksek olduğu belirlenmiştir. Kaytaz’ın (2005) araştırma bulguları, bu dönemde çocuklara yapılan yatırımların getirisinin yüksek, maliyetinin ise düşük olduğunu göstermektedir. Yine, aynı araştırmada, EÇBE’ye yapılacak her 1 liralık yatırımın ekonomiye 7 liraya kadar kazanç olarak döneceği belirtilmektedir. Ayrıca, Conti ve Heckman (2012) de yaşamın ilk yıllarında yapılan böylesi bir yatırımın ileriki yıllardaki getiriler için bir zemin oluşturduğunu belirtmektedir.

Bilindiği üzere, birçok kültürde çocuk yetiştirme ve bakımı kadınların görevi olarak kabul görmektedir. Bu nedenle, çocuk yetiştirme ve bakımı kadınların "evde/ücretsiz emeğiyle" ve "anne" olmanın gerektirdiği bir bilinç bağlamında yerine getirilmesi gereken cinsiyete dayalı bir toplumsal rol ve sorumluluk olarak düşünülmektedir (Pınarcıŏglu ve Çelik, 2015). Örneğin, Türkiye'de yapılan bir araştırmada, kadınların erkeklere göre çocuk bakımına 3 kat daha fazla zaman ayırmasına karşın, çocukların ev ödevlerine ise hemen hemen eşit zaman ayırdıkları tespit edilmiştir (Kasnakoğlu, Dayığlu ve Erdil, 1997). Bununla birlikte, Hacettepe Üniversitesi Nüfus Etütleri Enstitüsü’nün ([HÜNEE], 2014) yapmış olduğu 2013 y1lı Türkiye Nüfus ve Sağlık Araştırması’na katılan kadınların \%19'u çalışmama nedeni olarak çocuk bakmak zorunda olduklarını belirmişlerdir. Kızılgöl'ün (2012) araştırma bulgusu da burada belirtilenlerle örtüşmektedir. Söz konusu araştırmada, evli kadınların 0-5 yaş grubunda çocuklarının bulunması onların işgücüne katılımını sınırlandıran bir neden olarak ortaya konmuştur. Yapılan araştırmalar EÇBE hizmetlerinin arz boyutundaki genişlemenin kadınların işgücü piyasasını katılımını desteklediğini göstermektedir 
(Anderson ve Levin, 1999; ERG ve AÇEV, 2016; Kağıtçıbaş1 ve diğerleri, 2005; İlkkaracan, Kim ve Kaya, 2015; Staab ve Gerhard.2010). Örneğin, De Barros, Olinto, Lunde ve Carvalho (2013), EÇBE hizmetlerine ücretsiz erişim sağlanmasının çocuk sahibi kadınların istihdamı ve işgücü piyasasına katılımını kayda değer (\%36’dan \%40’a) artırdığını ortaya koymuşlardır. Bu artış oranı daha önce işgücü piyasasına dahil olmayan çocuk sahibi kadınlarda iki kat daha fazladır.

Aileler çocuk sahibi olduklarında, kaçınılmaz bir biçimde çocuk bakımı ve istihdama katılma ile ilgili çeşitli kararlarla karşı karşıya kalmaktadır. Dolayısıyla, ailelerin alacağı bu kararlardan ilki, çocuklarının bakımını öncelikle kimin üsteleneceğidir (Del Bolca, 2015). Ailelerin bu kararı üzerinde belirleyici olan birçok faktör bulunmaktadır. Örneğin, çocuğun yaşı, ailelerin inançları, öncelikleri, gelir düzeyi, çalışma saatleri veya ulaşım türü bu kararlar üzerinde belirleyici olan faktörlerin başında gelmektedir (Blau ve Hagy, 1998; Carlin, Davis, Krafft ve Toutd, 2019). Eğer, aileler çocuklarının bakımını kendileri üstlenemeyecekse, bu durumda ikinci en iyi seçenek olan büyük ebeveynlerden ya da yakın akrabalardan yardım alma yoluna başvurmaktadır. Bunun nedeni, büyük ebeveynlerin ya da yakın akrabaların bu konuda ailelere yardımcı olması yönünde geleneksel bir anlayışın olmasıdır. Dünya Bankası'nın (2015) ilgili araştırmasında, çalışan kadınlar kendileri veya eşleri çocuklara bakamadığında büyük ebeveynlerin çocuklarına bakmasını çalışamayan kadınlarla karşılaştırıldığında daha fazla istemektedir. Türkiye'de, Sağlık-Sen Stratejik Araştırmalar Enstitüsü’nün ([SASAM], 2018) kadın sağlık çalışanları üzerinden yürütmüş olduğu araştırmada, katılımcıların \%36,4'ünün çocuklarının bakımı büyük ebeveynler tarafından üstlenildiğini, \%3,7’ü ise yakın bir akrabasının üstlendiğini belirtmiştir. Alanyazında yapılan araştırmalar, büyük ebeveynlerin çocuk bakımında annelere destek vermesi durumunun kadınların işgücü piyasasına katılma kararlarında belirleyici olduğunu göstermektedir (Aassve, Arpino ve Goisis, 2012; Del Bolca, 2015). Söz konusu bu konuyla ilgili olarak İtalya'da yapılan bir araştırma; büyük ebeveynlerin çocuk bakımını üstlenmiş olmalarının, annelerin işgücü piyasasına katılımı üzerindeki etkisinin pozitif ve istatistiksel olarak da anlamlı olduğunu ortaya koymuştur. Bu etki düşük eğitim düzeyine sahip kadınlar ve genç anneler arasında; ülkenin merkez ve kuzeyinde daha güçlüdür (Arpino, Pronzato ve Tavares, 2012).

Yukarıda belirtilen ilk iki seçenekten herhangi birinin gerçekleşmemesi durumunda, aileler üçüncü ve dördüncü seçenek arasında yer alan; kurumsal (kamu veya özel kurumsal bakım hizmeti) ile evde özel bakım hizmetine başvurmayı gündeme alabilmektedir. Ailelerin belirtilen bu son iki seçenekten birine karar verirken, çocuğun bakımını üstlenecek kurum veya kişiye güvenip güvenmeyeceğine, her iki seçeneğin aile bütçesine olası maliyetinin ne kadar olacağına ve yine her iki seçenek çerçevesinde yapacakları tercihin kendilerinin beklentilerine kadar ne kadar uygun olup olmadığına 
da karar vermek durumundadır (Del Bolca, 2015). Ancak, gerek kamu gerekse özel sektör tarafından sağlanan nitelikli ve yeterli EÇBE hizmetlerine erişimde sorunlar olması ailelerin bu yönde yapacakları tercihlerini sınırlandırabilmektedir (World Bank, 2015a, 2015b, 2016). Örneğin, Türkiye'de son yıllarda gerek kamu gerekse özel kurumsal bakım hizmetlerinin yaygınlaştırılması yönünde yoğun bir çaba gösterilmesine karşın, yine OECD (Organisation for Economic Cooperation and Development) ülkelerinin gerisinde olduğu gözlenmektedir (İlkkaracan, Kim ve Kaya, 2015; Dünya Bankas1, 2015; OECD, 2017). EÇBE döneminde, kurumsal bakım hizmeti veren kamu veya özel bakım kurumlarının arz boyutunda yaşanan niceliksel ve niteliksel anlamdaki sorunların olması, ailelerin bu seçeneğe başvurmalarını sınırlandırdığı söylenebilir (Boğaziçi Üniversitesi Sosyal Politika Forumu, 2009; World Bank, 2015a).

Yukarıda yapılan açıklamaların dışında, ailelerin kurumsal bakım hizmetine başvurmalarını sınırlandıran nedenlerden biri de çocuğun yaşı olduğu görülmektedir. Aileler, genellikle, küçük yaş gruplarındaki çocukların bakımlarında kurumsal destek alma yerine, ya kendileri bakmakta yahut büyük ebeveynlerden destek almakta veya evde bakım hizmetlerine başvurmaktadır (Beşpınar, 2016). Dolayısıyla, ilk üç seçenek bağlamında; çocuklarının bakımına çözüm arayışında başarısız olan aileler, dördüncü ve sonuncu seçenek olan evde ücretli bakım hizmetine başvurabilmektedir. Bu durum biraz daha somut bir ifadeyle, çocukların bakımı için ailelerin "ücretli özel çocuk bakıcısı” hizmetine yönelmeleridir. Türkiye'de 2013 yılında çalışan kadınların \%25,6’sı çocuklarının bakımında ücretli bakım hizmetlerinden yararlanmaktadır (HÜNEE, 2014). SASAM'ın (2018) yukarıda belirtilen araştırmasında, sağlık çalışanları arasında ücretli bakım hizmetlerinden yararlananların oranı ise \%26,4’tür. Bu veriler dikkate alındığında, söz konusu ailelerin bu yöndeki tercihinin, bir anlamda, işgücü piyasasında ücretli kadın emeğine olan talebi de artırdığ1 söylenebilir. Ancak, Paker ve Uysal'ın (2016) çalısmasına katılan kadınlar evde ücretli bakım hizmeti veren bakıcılarının çocuklarına gerekli bakımı ve eğitimi sağlama noktasında kuşkularının olduğunu belirtmiştir. Örneğin, Baytar'ın (2014) araştırması evde ücretli bakım hizmeti veren kadınların bakımını üstlendikleri çocuklardaki dil gelişim sorunlarının daha fazla olduğunu ortay koyması, yukarıda belirtilen kadınların kuşkularında bir doğruluk payı olduğunu göstermektedir

Türkiye'de ilgili alanyazında bakıcı hizmetlerine yönelik araştırmalar bulunmaktadır (Baytar, 2014; Dikmen ve Kart, 2017; Doğan, 2018; Kakıc1, Emeç ve Üçdoğruk, 2007; Koyuncu, 2018; Küçük, 2009; Suğur, Suğur ve Şavran, 2008; Yaman, 2010). Ancak, yapılan bu araştırma yukarıda belirtilen araştırmalardan farklı olarak doğrudan ailelerin evde ücretli çocuk bakımı hizmetlerine olan talepleri üzerine yoğunlaşmıştır. Dolayısıyla, bu araştırmanın alanyazında diğer araştırmaların eksik bıraktığı bir boyutu tamamlamanın ötesinde, konuyla ilgili yapılan ilk araştırma olma özelliğini taşıdığı 
söylenebilir. Buna ek olarak, araştırmada elde edilen bulguların konuyla ilgili farklı çalışmalara ışık tutacak nitelikte olduğunun da belirtilmesi gerekmektedir.

Yukarıda yapılan açıklamalar çerçevesinde bu araştırmanın genel amacı, ailelerin EÇBE döneminde evde ücretli bakım hizmetlerine yönelik talepleri üzerinde belirleyici olan nedenler ve süreçte ortaya çıkan sorunların belirlenmesidir. Araştırmada aşağıdaki sorulara yanıt aranmıştır:

1. Evde ücretli bakım hizmeti talep eden ailelerin;

a. Bu hizmete talepte bulunma nedenleri nedir?

b. Bakım hizmeti verecek olan kadınlarda aradıkları özellikler nedir?

2. Evde ücretli bakım hizmeti talep eden ailelerin;

a. Bakıcıların yaşı, bakım yeri, bakım süresi ve çocuklarını bakıcıya verme yaşı ilgili tercihleri nelerdir?

b. Bakıcıları işe alma, ek görev talep etme ile ilgili tercihleri nelerdir?

3. Evde ücretli bakım hizmeti talep eden ailelerin;

a. Bakıcılara verdikleri ücret ne kadardır?

b. Bakıcılara verilen ücret aile bütçesini zorlamakta mıdır?

4. Evde ücretli bakım hizmeti talep eden aileler gün içerisinde bakıcılarını denetlemekte ve kontrol etmekte midir?

5. Evde ücretli bakım hizmeti talep eden ailelerin;

a. Bakım hizmeti aldıkları kadınlardan memnun olup olmama durumları nedir?

b. Bakım hizmeti aldıkları kadınlarla daha ne kadar devam etmeyi düşünmektedir?

c. Bakım hizmeti aldıkları kadınlarla yaşadıkları sorunlar nedir?

\section{YÖNTEM}

\section{Araştırma Deseni}

Tarama modeli araştırmaları bir grubun belirli özelliklerini ortaya koymak için verilerin toplanmasını amaçlayan araştırmalardır (Büyüköztürk, Çakmak, Akgün, Karadeniz ve Demirel, 2013). Bir araştırmanın tarama deseninde bir araştırma olarak nitelendirilmesi için birkaç niteliğe sahip olması gerekmektedir. Bunlar; (1) Araştırma örneklemini temsil edecek bir evren ve örnekleme sahip olması, (2) verilerin standart bir veri toplama aracı (anket formu, gözlem çizelgesi ya da görüşme yönergesi vb.) ile sistemli bir biçimde toplanması ve (3) verilerin istatistiksel olarak çözümlenebilmesidir (De Vaus, 1990 akt. Şavran, 2012). Bütün bunlar dikkate alındığında, ailelerin EÇBE döneminde evde ücretli bakım hizmetlerine olan talebin nedenlerini ve bu süreçte 
karşılaştıkları sorunları ortaya koymayı amaçlayan bu araştırmanın, tarama modelinde betimsel bir araştırma olduğu söylenebilir.

\section{Evren ve Örneklem}

Araştırmanın çalışma evreni, Ankara ve Kastamonu illerinde EÇBE döneminde evde ücretli bakım hizmetinden yararlanılan ailelerden oluşturmaktadır. Ancak, araştırmanın çalışma evreninin büyüklügü hakkında tam bir bilgiye ulaşmak mümkün olmamıştır. Söz konusu bu duruma bağl1 olarak tesadüfi ve tesadüfi olmayan örnekleme yöntemlerinden birine dayalı olarak bir örneklem grubu oluşturulamamıstır. Fraenkel ve Wallen (2009) böylesi durumlarda kolay örnekleme yöntemine başvurabileceğini belirtmektedir. Kolay örnekleme yöntemi araştırmacıya kendi yakın çevresinde erişebildiği ve istekli kişileri örnekleme dahil etmesine izin vermektedir (Creswell, 2012).

Kolay örnekleme yöntemi araştırmacıya zaman, para ve işgücü kayıplanı bakımından tasarruf sağlayan bir yöntem olarak bilinmektedir (Büyüköztürk ve diğerleri, 2013). Ancak, bu yönteme bağl1 olarak elde edilen araştırma sonuçlarının güvenirliği oldukça düşüktür. Bu nedenle, araştırma sonuçlarının evrene genellenmesi söz konusu değildir (Büyüköztürk ve diğerleri, 2013; Creswell, 2012; Fraenkel ve Wallen, 2009).

Yukarıda yapılan açıklamalar çerçevesinde kolay örnekleme yöntemine başvurularak bir çalışma grubu oluşturulmuştur. Araştırmaya katılan çalışma grubunda 218 aile bulunmaktadır. Araştırmanın çalışma grubunda bulunan ailelerin sosyo-demografik değişkenlere yönelik olarak; araştırmaya katılan ebeveynin cinsiyeti, çocuğun kiminle birlikte yaşadığı, anne-baba eğitim, anne-baba meslek, anne-baba çalışma durumu, ailenin aylık ortalama gelir düzeyi, oturulan evin mülkiyet durumu ve türü, kira/lojman ücreti ve evde yaşayan kişi sayısına ilişkin bilgilere Tablo 1'de yer verilmiştir.

Tablo 1. Ailelerin Sosyo-demografik değişkenleri

\begin{tabular}{|c|c|c|c|c|c|}
\hline Değişken & $\mathrm{f}$ & $\%$ & Değişken & $\mathrm{f}$ & $\%$ \\
\hline Ebeveynin cinsiyeti & & & Aile gelir düzeyi & & \\
\hline Kadin & 172 & 78,9 & 5000 TL* ve altı & 74 & 34,68 \\
\hline Erkek & 46 & 21,1 & 5001-7500 TL & 102 & 46,8 \\
\hline \multirow[t]{2}{*}{ Toplam } & 218 & 100,0 & 7501-10000 TL & 37 & 17,0 \\
\hline & & & 10001 TL ve üstü & 5 & 2,3 \\
\hline Çocuğun kiminle yaşadığı & & & Toplam & 218 & 100,0 \\
\hline Anne ve baba ile birlikte & 173 & 79,4 & & & \\
\hline Anne ile birlikte & 45 & 20,6 & Evin mülkiyeti & & \\
\hline \multirow[t]{2}{*}{ Toplam } & 218 & 100,0 & Kendime-eşime ait & 124 & 56,9 \\
\hline & & & Lojman & 14 & 6,4 \\
\hline Anne eğitim & & & Kira & 75 & 3,4 \\
\hline Ortaokul/ilköğretim & 5 & 2,3 & Başkasına ait, kira verilmiyor & 5 & 2,3 \\
\hline Lise & 24 & 11,0 & Toplam & 218 & 100,0 \\
\hline Yükseköğretim & 168 & 77,1 & & & \\
\hline
\end{tabular}




\begin{tabular}{|c|c|c|c|c|c|}
\hline Lisans üstü & 21 & 9,9 & Kira/Lojman ücreti & & \\
\hline \multirow[t]{2}{*}{ Toplam } & 218 & 100,0 & 250 TL ve altı & 3 & 1,4 \\
\hline & & & $251-500 \mathrm{TL}$ & 30 & 1,8 \\
\hline Baba eğitim & & & 501-750 TL & 43 & 19,7 \\
\hline Ortaokul/ilköğretim & 3 & 1,6 & 751 TL ve üzeri & 13 & 6,0 \\
\hline Lise & 23 & 10,6 & Kira ücreti ödemiyor & 129 & 59,2 \\
\hline Yükseköğretim & 164 & 75,2 & Toplam & 218 & 100,0 \\
\hline Lisans üstü & 28 & 12,8 & & & \\
\hline \multirow[t]{2}{*}{ Toplam } & 218 & 100,0 & Hanehalk1 sayısı & & \\
\hline & & & Üç kişi & 80 & 36,7 \\
\hline Anne Çalışma durumu & & & Dört kişi & 96 & 44,0 \\
\hline Çalışıyor & 216 & 99,1 & Beş kişi & 34 & 15,6 \\
\hline Çalışmıyor & 2 & 0,9 & Alt kişi ve üzeri & 8 & 3,7 \\
\hline Toplam & 218 & 100,0 & Toplam & 218 & 100,0 \\
\hline \multicolumn{6}{|l|}{ Baba Çalışma durumu } \\
\hline Çalışıyor & 215 & 98,7 & & & \\
\hline Çalışmıyor & 3 & 1,3 & & & \\
\hline Toplam & 218 & 100,0 & & & \\
\hline
\end{tabular}

*Türk Liras1

Tablo 1'de görüldüğü üzere, araştırmaya katılan ebeveynlerin \%78,9’u kadın, \%21,1’i erkektir. Ailelerin \%79,4'ünde çocuğun kendi ebeveynleri birlikte yaşadığı, \%20,6'sın da anneleri ile birlikte yaşadığı anlaşılmaktadır. Araştırmaya katılan ailelerde ebeveynlerin eğitim düzeylerine bakıldığında annelerin \%2,5’i ilköğretim, \%11'i lise, \%77,1'i üniversite, \%09,6'sı lisansüstü mezunudur. Babaların ise \%1,6’s1 ilköğretim, \%10,6's1 lise, \%75,2'si yükseköğretim, \%12,8’i lisansüstü mezunu olduğu görülmektedir.

Evde ücretli bakım hizmeti talebinde bulunan ailelerdeki ebeveynlerden annelerin \%99,7'si, babaların ise \%98,7'si çalıştı̆̆1 görülmektedir. Yine, Tablo 1'deki veriler ailelerin gelir düzeyleri bakımından ele alındığında, ücretli bakım hizmeti talep eden ailelerin \%34’ü 5000 TL ve altında bir gelire sahip iken, \% 46,8’i 5001-7500 TL arasinda, \%17’si 7501-10000 TL arasinda ve \%2,5’i de 10001 TL ve üzerinde bir gelire sahiptir.

Tablo 1'deki bilgilere göre, evde ücretli bakım hizmeti talep eden ailelerin \% 56'sının oturduğu evin mülkiyeti kendisine ait olduğu, \%6,4’ünün lojmanda \%3,4’ünün kirada oturduğu, \%2,3’ünün de oturduğu evin başka birine ait olduğu; ancak herhangi bir kira ücreti ödemediği görülmektedir. Kirada/lojmanda oturan ailelerin \%1,4’ü 250 TL ve altında kira ücreti öderken, \%13,8`i 251-500 TL arasında, \%19,7'si 501-750 TL arasında ve \% 6'sı da 751 TL ve üzerinde kira ücreti ödemektedir. Ailelerin \%59,2'sinin ise herhangi bir kira ücreti ödemediği görülmektedir. Son olarak, araştırmaya katılan ailelerin \%36,7'sinde üç kişi bulunurken, \%44'ünde dört, \% 15,6'sında beş kişi ve \%3,7'sinde ise altı ve üzerinde kişi bulunmaktadır. 


\section{Veri Toplama Arac1}

Araştırmada veri toplama aracı olarak, sosyal bilimlerde en sık kullanılan veri toplama tekniklerinden biri olan anket kullanılmıştır. Anketler belli bir konuyla ilgili çok sayıda sorudan oluşan ölçme araçları olarak bilinir (Doğan, 2013). Buna göre anket; insanların yaşam koşullarının yanı sıra davranışlarını, inançlarını veya tutumlarını betimleye yönelik bir dizi sorudan oluşan standart bir veri toplama aracıdır (Balc1, 2011; Thomas, 1998 akt. Büyüköztürk ve diğerleri, 2013).

EÇBE döneminde ücretli bakım hizmetlerine başvuran ailelerin bu taleplerine ilişkin verilerin elde edilebilmesi için araştırmacı tarafından "Erken Çocukluk Döneminde Bakıcı Hizmetlerine Talep Anketi” geliştirilmiştir. Söz konusu anketin geliştirilmesinde beş aşamalı bir süreç izlenilmiştir. İlk aşamada, uygulamada görev yapan öğretmenler ve evde özel bakım hizmeti alan ailelerle görüşülerek madde havuzunda yer alacak sorular belirlenmiştir. İkinci aşamada madde havuzunda yer alan sorular bir elemeden geçirilmiss ve bunun ardından taslak bir veri toplama aracı oluşturulmuştur. Üçüncü aşamada taslak olarak hazırlanan veri toplama aracı aralarında alan uzmanları, öğretmeneler ve ailelerin de bulunduğu 15 kişilik bir uzman grubunun görüşüne sunulmuştur. Böylelikle, veri toplama aracının kapsam geçerliliği sağlanmaya çalışılmıştır. Dördüncü aşamada ise uzman görüşü grubundan gelen görüşler gözden geçirilerek veri toplama aracına son hali verilmiştir. Beşinci ve son aşamada ise veri toplama aracında yer alan soruların okunup anlaşılmasında bir sorun olmadığının belirlenmesi için üç kişi ile uygulama öncesinde ön bir uygulama/pilot çalışması yapılmıştır. Bu çalışma sonucunda ankette yer alan soruların okunması ve anlaşılmasında bir sorun olmadığı anlaşılmıştır. Bütün yapılan bu çalışmaların ardından veri toplama sürecine geçilmiştir.

Araştırma verilerini elde etmek için geliştirilen anket, iki kısımdan oluşmaktadır. Söz konusu anketin ilk kısmında araştırmaya katılan ailelerin sosyo-demografik değişkenlerini belirmeye yönelik sorular bulunmaktadır. İkinci kısımda ise ailelerin evde ücretli bakım hizmetlerine yönelik talepleri ile ilişkili olan nedenleri ve bu süreçte yaşanan soruları ortaya koymaya yönelik kapalı ve açık uçlu sorulara yer verilmiştir.

\section{Verilerin Toplanmas1}

Araştırmanın veri toplama aracı Ankara ve Kastamonu illerinde uygulanmıştır. Verilerin toplanmasında iki farklı stratejiye başvurulmuştur. Bunlardan ilkinde, araştırmacı bulunduğu ilde kendisi uygulama yapmıştır. İkincisi ise araştırmacının her iki ildeki arkadaşları aracılı̆̆ıyla yakın çevrelerinde EÇBE döneminde evde bakım hizmetlerine başvuran ailelere bu anketlerin 
ulaştırılması sağlanmıştır. Araştırmanın verilerinin toplanması 2017'de Nisan ve Aralık ayları arasında gerçekleştirilmiştir.

\section{Verilerin Çözümlenmesi}

Araştırmada elde edilen veriler betimsel istatistiklerden yararlanılarak çözümlenmiştir. Veri toplama aracında yer alan sorular arasında bulunan; ailelerin neden evde ücretli bakım hizmetlerine gereksinim duyduğu, bakıcılarda aradıkları özellikler, bakıcılardan hangi eğitsel faaliyetleri yapmalarını istedikleri, bakıcıdan memnun olup olmadıkları ve bakıcılarıla hangi sorunları yaşadıklarına ilişkin sorular açık uçlu sorulardır. Araştırmaya katılanların bu sorulara verdikleri yanıtlar ilk önce kendi içinde sınıflandırılmıştır. Bunun ardından yine betimsel istatistiklere dayalı olarak sunulmuştur.

\section{BULGULAR}

Araştırmada elde edilen bulgular araştırmanın alt amaçlarına uygun olarak aşağıda sırasıyla ele alınmıştır.

Ailelerin evde özel ücretli bakım hizmetine talepte bulunmalarının nedenlerine ilişkin bulgular Tablo 2'de verilmiştir.

Tablo 2. Ailelerin bakıcı hizmetlerine talepte bulunmalarının nedenleri

\begin{tabular}{lrr}
\hline & $\mathrm{f}$ & $\%$ \\
\hline Çocuğun düzeninin bozulmaması & 1 & 0,4 \\
Çocuğun kalabalık ortama sokulmak istenilmemesi & 0,4 \\
Çocuğun uyku düzeninin bozulmak istenilmemesi & 1 & 0,4 \\
Çocuğun kreşe gitmek istememesi & 1 & 0,4 \\
Çocuğun oyuncaklarını istemesi & 1 & 0,9 \\
Çocuğun yabancilık çekmesi & 2 & 0,9 \\
Çocuğun evde yatağını istemesi & 2 & 0,9 \\
Yakında kreş olmaması & 2 & 0,9 \\
Kendi evlerinin müsait olması & 2 & 1,3 \\
Bakıcının ev işlerine yardım etmesi & 3 & 1,3 \\
Çocuğun hasta olmasindan endişelenilmesi & 3 & 1,3 \\
Çocuğun evde daha mutlu olması & 3,0 \\
Aile büyüklerinin yanlarında olmaması & 3 & 4,3 \\
Çocuğun tuvalet eğitimini kazanmaması & 7 & 4,8 \\
Ev ortamının daha güvenli olması & 10 & 5,2 \\
Bakacak kimse olmaması & 11 & 8,7 \\
Çocuğun yaşının küçük olması & 12 & 17,0 \\
Anne-babanın çalışması & 20 & 47,8 \\
& 108 & 100,0 \\
\hline
\end{tabular}

Tablo 2 incelendiğinde, EÇBE döneminde evde özel bakıcı talebinde bulun ailelerin bu taleplerinin arakasında en önemli neden \% 47,8’lik bir oranla anne-babanın çalışmasıdır. Bunu sırasıyla çocuğun 
yaşının küçük olması ve kendileri dışında çocuklara bakacak kimsenin olmaması izlemektedir (sırasıyla \%17,0 ve \%8,7). Araştırmaya katılan ailelerin bakıcı hizmeti talepleri üzerinde en az etkili nedenler ise çocuğun uyku düzeninin bozulmasını istememeleri $(\% 0,4)$, çoğun kalabalık ortama sokulmak istenmemesi $(\% 0,4)$ ve çocuğun kreşe gitmek istememesi $(\%, 0,4)$ olduğu görülmektedir.

Tablo 3'te evde ücretli bakım hizmetlerine talepte bulunan ailelerin çocuklarının bakımını üstlenecek bakıcılarda aradıkları özelliklere ilişkin bilgiler yer almaktadır.

Tablo 3. Ailelerin bakıcılarda aradıkları özellikler

\begin{tabular}{|c|c|c|}
\hline & & $\%$ \\
\hline Çocuğa yaklaşımı & 2 & 0,5 \\
\hline Dürüst olmas1 & 2 & 0,5 \\
\hline İlgili olmas1 & 2 & 0,5 \\
\hline Medeni durumu/evli olması & 2 & 0,5 \\
\hline Sigara kullanmaması & 3 & 0,7 \\
\hline Bakımlı olması & 5 & 1,1 \\
\hline Çocuk sahibi/anne olması & 5 & 1,1 \\
\hline Ekonomik durumu & 6 & 1,4 \\
\hline Tecrübeli olması & 6 & 1,4 \\
\hline Becerikli olması & 10 & 2,3 \\
\hline Giyimi-duruşu & 10 & 2,3 \\
\hline Samimi olmasi & 10 & 2,3 \\
\hline Çalışkan olması & 13 & 3,0 \\
\hline Eve gelebilmesi & 15 & 3,4 \\
\hline İletişiminin iyi olması & 15 & 3,4 \\
\hline Yakin olmasi & 15 & 3,4 \\
\hline Güler yüzlü olması & 23 & 5,3 \\
\hline Çocuğu sevmesi & 26 & 6,0 \\
\hline Tanıdık olması & 30 & 6,9 \\
\hline Temiz olması & 38 & 8,7 \\
\hline Eğitimli olması & 43 & 9,9 \\
\hline Referansli olmas1 & 43 & 9,9 \\
\hline Yaş1 & 45 & 10,3 \\
\hline Güvenilir olması & 46 & 10,6 \\
\hline \multirow[t]{2}{*}{ Diğer } & 10 & 2,3 \\
\hline & & 100,0 \\
\hline
\end{tabular}

Tablo 3’te görüleceği üzerine, EÇBE hizmetlerine başvuran ailelerin çocuklarının bakım sorumluluğunu üstlenecek bakıcılardan en fazla talep ettikleri özellikler arasında sırasıyla; bakıcının güvenilir olması (\% 10,6), bakıcının yaşı $(\% 10,3)$ bakıcının referansının olması $(\% 9,9)$ ve eğitimli olması $(\% 9,9)$ yer almaktadır. Yine Tablo 3 'te yer alan bulgulara göre, ailelerin bakıcılarda en az aradıkları özellikler ise bakıcının çocuğa yaklaşımı (\%0,5), dürüst olması (\%0,5), medeni durumu/evli olması $(\% 0,5)$, sigara kullanmaması $(\% 0,7)$ ve bakımlı olması $(\% 0,1,1)$ olduğu anlaşılmaktadır.

Ailelerin çocuklarına bakıcı tercih ederken yaş sınırı arama durumlarına ilişkin bulgular Tablo 4'te sunulmuştur. 
Tablo 4. Ailelerin bakıcılarda yaş sınırı arama durumu

\begin{tabular}{lrr}
\hline & $\mathbf{f}$ & $\mathbf{\%}$ \\
\hline Evet & 103 & 47,2 \\
Hayır & 115 & 52,8 \\
& 218 & 100,0 \\
\hline
\end{tabular}

Tablo 4'teki verilere göre araştırmaya katılanların \% 47,2'si bakıcı tercih ederken yaş sınırını göz önünde bulundururken, \%52,8’i ise bulundurmadığını belirtmiştir.

Ailelerin bakıcı tercihlerinde neyin belirleyici olduğuna ilişkin bulgular Tablo 5’te verilmiştir.

Tablo 5. Ailelerin bakıcı tercihinin belirleyicileri

\begin{tabular}{lrr}
\hline & $\mathrm{f}$ & $\%$ \\
\hline Eğitim & 9 & 4,1 \\
Deneyim & 32 & 14,7 \\
Tanidık & 114 & 33,5 \\
Referans & 63 & 28,9 \\
& & 100,0 \\
\hline
\end{tabular}

Tablo 5’teki verilere göre, araştırmaya katılanların \% 4,1'i bakıcının eğitiminin kendileri için bir tercih nedeni olarak belirtirken, \% 14,7'si deneyimli olmasının, \% 33,5'i tandık olmasının ve \% 28,9'da referansının iyi olmasının bir tercih nedeni olduğunu ifade etmiştir.

Tablo 6'da ailelerin çocuklarını bakımını üstelenin bakıcıları işe alırken herhangi bir sağlık raporu talep etme durumlarına ilisskin verilere yer almaktadır.

Tablo 6. Sağlik raporu talep etme durumu

\begin{tabular}{lrr}
\hline & $\mathbf{f}$ & $\mathbf{\%}$ \\
\hline Evet & 34 & 15,6 \\
Hayir & 184 & 86,4 \\
& & 100,0 \\
\hline
\end{tabular}

Tablo 6'daki verilere göre, araştırmaya katılan ailelerin \% 15,6'sı çocuklarının bakımını üstlenecek bakıcılardan onların sağlık durumunu gösteren bir rapor talep ettiklerini, \% 84,4’ü ise bu yönde herhangi bir talepte bulunmadıklarını belirtmiştir.

Ailelerin çocuklarını bakıcıya kaç aylıktan itibaren verdiklerine ilişkin bulgular Tablo 7'de sunulmuştur.

Tablo 7. Çocukların kaç aylıktan itibaren bakıcıya verildikleri

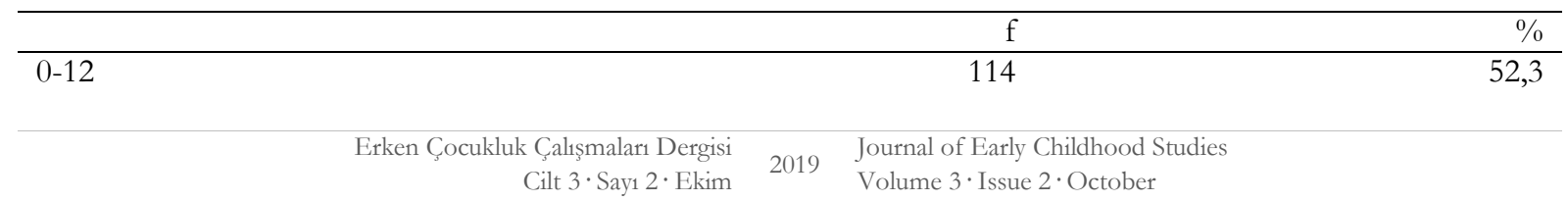


Tablo 7'den görüleceği üzere, araştırmaya katılan ailelerin \% 52'si çocuklarını 0-12 ay arasında iken bakıcıya verdiklerini belirtirken, \% 34,4'ü 12-24 ay arasında, \% 11,9’u 24-36 ay arası ve \% 1,4'ü ise 36-48 ay arasında bakıcıya verdiklerini ifade etmiştir.

Araştırmaya katılan ailelerde bakıcıların çocuklarının bakımıyla ne kadar süredir ilgilendiklerine ilişkin bilgiler Tablo 8'de yer almaktadır.

Tablo 8. Bakıcılarının ailelerin çocuklarının bakım hizmetini ne kadardır süredir yerine getirdiği

\begin{tabular}{lrr}
\hline & $f$ & $\%$ \\
\hline 1 yildan az & 58 & 26,6 \\
1 yil & 55 & 25,7 \\
2 yil & 41 & 18,8 \\
3 yil & 23 & 10,6 \\
4 yil ve daha fazla & 40 & 18,3 \\
& & 100,0 \\
\hline
\end{tabular}

Tablo 8'de araştırmaya katılanların \% 26,6'sı 1 yıldan daha az süredir çocukların bakımı için bakıcı hizmetinden yararlandıklarını belirtirken, \% 25'si 1 yıldır, \% 18,8’i 2 yıldır, \% 10,6’s1 3 yıldır ve \% 18,3’ü de 4 yıl ve daha fazla bir süredir bakıcılarının çocuklarının bakımın hizmetini üstlendiğini belirtmiştir.

Çocuğun bakıcıyla geçirdiği süre ile ilgili bilgiler Tablo 9'da verilmiştir.

Tablo 9. Çocuğun bakıcıyla geçirdiği süre

\begin{tabular}{lrr}
\hline & $\mathrm{f}$ & $\%$ \\
\hline 2 saat & 4 & 1,9 \\
3-4 saat & 20 & 9,2 \\
5-6 saat & 77 & 35,3 \\
7-8 saat & 97 & 44,5 \\
9 saat ve üzeri & 20 & 9,2 \\
& & 100,0 \\
\hline
\end{tabular}

Tablo 9'dan izleneceği üzere, araştırmaya katılan aileler \%1,9'u çocukların bakıcısıyla 4 saat bir arada olduğunu belirtirken, \%9,2'si 3-4 saat, \%35,3'ü 5-6 saat, \%44,5’i 7-8 saat ve \% 9,2'si de 9 saat ve üzerinde bir arada olduğunu ifade etmiştir.

Bakıcıdan ailelerin çocuklarına uygulamasını talep ettikleri herhangi bir eğitsel faaliyet olup olmadığına ilişkin bulgular Tablo 10'da verilmiştir. 
Tablo 10. Bakıcılardan çocuklara eğitsel faaliyet uygulamalarını talep etme durumu

\begin{tabular}{lrr}
\hline & $\mathbf{f}$ & $\mathbf{\%}$ \\
\hline Evet & 87 & 37,1 \\
Haylr & 131 & 62,9 \\
& & 100,0 \\
\hline
\end{tabular}

Tablo 10'dan görüleceği gibi, ailelerin \%37,1'i bakıcılarından çocuklarına eğitsel faaliyet uygulamalarını talep ettiklerini, \% 62,9’u ise böyle bir taleplerinin olmadığını söylemiştir.

Tablo 11'de ailelerin bakıcılardan uygulamaları istedikleri eğitsel faaliyetlere ilişkin bilgiler bulunmaktadır.

Tablo 11. Bakıcılardan istenilen eğitsel faaliyetler

\begin{tabular}{lrr}
\hline & $\mathrm{f}$ & $\%$ \\
\hline Müzik aletleri çalma & 2 & 1,3 \\
Ahlak eğitimi & 2 & 1,3 \\
Televizyondan uzak durması & 2 & 1,3 \\
Renk bilgisi & 2 & 1,3 \\
Çizgi film/CD izleme & 3 & 2,0 \\
Yaşıtlarıyla bir arada oynaması & 3 & 2,0 \\
Zeka oyunları & 3 & 2,0 \\
Eşleştirme kartları & 4 & 2,6 \\
Küçük kas becerisi gelişimi & 4 & 2,6 \\
Sayı sayma & 4 & 2,6 \\
Fiziksel faaliyetler & 4 & 2,6 \\
Yapboz & 4 & 3,3 \\
Boyama yapması & 5 & 5,3 \\
Masal/hikaye kitabi okuma & 8 & 6,0 \\
Çocuk şarkiları & 9 & 6,0 \\
Beceri oyunları & 9 & 7,9 \\
Konuşma ile ilgili faaliyetler & 9 & 7,9 \\
Resim yapması & 12 & 9,3 \\
Eğitsel oyun & 12 & 25,8 \\
Diğer & 14 & 6,6 \\
& 39 & 100,0 \\
\hline
\end{tabular}

Tablo 11'e göre, ailelerin bakıcılardan en fazla istedikleri eğitsel faaliyetleri arasında sırasıyla eğitsel oyun $(\% 25,8)$, resim yapma $(\% 9,3)$, beceri oyunları $(\% 7,9)$ ve çocuk şarkıları $(\% 7,9)$ olduğu anlaşılmaktadır. Ailelerin bakıcılardan en az istedikleri eğitsel faaliyetler arasında ise müzik aletleri çalma $(\% 1,3)$, ahlak eğitimi $(\% 1,3)$ ve televizyon izlememelerini isteme $(\% 1,3)$ bulunmaktadır.

Çocuğun bakımının nerede yapıldığına ilişkin bulgular Tablo 12'de yer almaktadır.

Tablo 12. Çocuğun bakımının nerede yapıldı̆̆1

\begin{tabular}{lrr}
\hline & $f$ & $\%$ \\
\hline Kendi evimde & 172 & 78,9 \\
Bakicının evinde & 46 & 21,1 \\
& & 100,0 \\
\hline
\end{tabular}


Tablo 12'de yer alan bulgulara göre, ailelerin \% 78,9’u bakıcıların çocuğun bakımını kendi evinde yaptığını ifade ederken, \% 21,1’i ise bakıcının evinde yapıldığını belirtmiştir.

Ailelerin bakıcılardan çocuk bakımı dışında ek görevler isteme durumuna ilişkin bulgulara Tablo 13 'te verilmiştir.

Tablo 13. Bakıcılara çocuk bakımı dışında ek görevler verme durumu

\begin{tabular}{lrr}
\hline & $\mathrm{f}$ & $\%$ \\
\hline Evet & 64 & 29,4 \\
Hayir & 154 & 70,6 \\
& & 100,0 \\
\hline
\end{tabular}

Tablo 13’teki bulgular göz önünde bulundurulduğunda ailelerin \% 29,4’ü çocuklarının bakımını üstlenen bakıcılara ek görev verdiğini, \%70,6’sı ise herhangi bir ek görev vermediğini belirtmiştir.

Bakıcılara çocuk bakımı dışında verilen ek görevlerin neler olduğuna ilişkin bulgular Tablo 14'te sunulmuştur.

Tablo 14. Bakıcılara çocuk bakımı dışında verilen ek görevler

\begin{tabular}{lrr}
\hline & $\mathrm{f}$ & $\%$ \\
\hline Çocukla haftada bir kurabiye ya da kek yapması & 1 & 1,2 \\
Bazen bulaşık makinesindekileri dizmesi & 1 & 1,2 \\
Bazen çamaşırları asması & 1 & 1,2 \\
Bazen çocuk hastalandı̆̆ında doktora götürmesi & 1 & 1,2 \\
Ütü yapması & 6 & 7,0 \\
Ortalı̆̆ı düzenlemesi & 8 & 9,3 \\
Çocuk odasını temizleme ve düzenleme & 32 & 37,2 \\
Öğle yemeği hazırlaması & 36 & 41,9 \\
& & 100,0 \\
\hline
\end{tabular}

Tablo 14’teki veriler dikkate alındığında, ailelerin bakıcılara en fazla verdikleri ek görevler sırasıyla çocuğa öğle yemeği hazırlama $(\% 41,9)$, çocuk odasını temizleme ve düzenleme $(\% 37,2)$ ve ortalığın düzenlenmesi $(\% 9,3)$ yer almaktadır. Bunun dışında ailelerin bakıcılardan nadirde olsa çocuklarıyla birlikte kurabiye veya kek yapma, bulaşıkları dizme (\%1,3), çamaşırları asma, ütü yapma $(\% 1,3)$ gibi ek görevler istedikleri de olmaktadır.

Ailelerin takip amaçlı bir cihaz kullanma durumlarına ilişkin bulgular Tablo 15’te verilmiştir.

Tablo 15. Ailelerin çocukları bakıcısılla beraberken takip amaçlı cihaz kullanma durumu

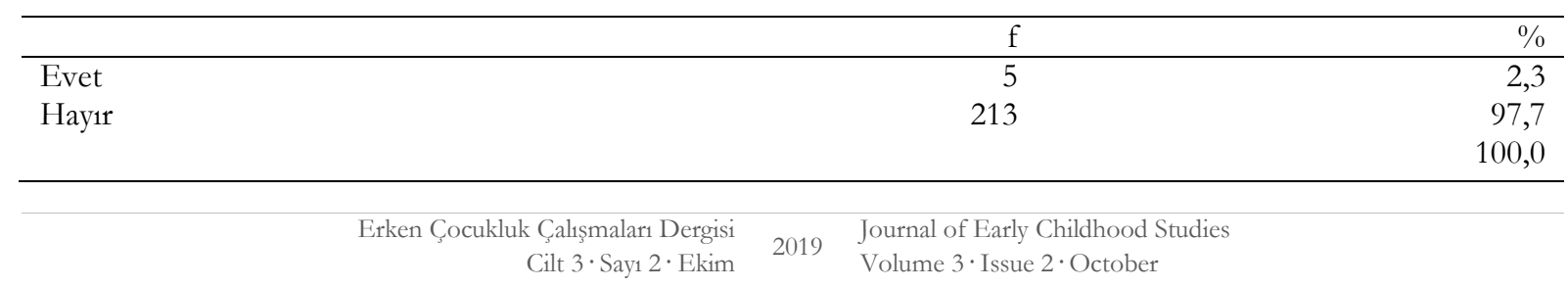


Tablo 15'teki verilere göre, ailelerin yalnızca \% 2,5'i çocuğu bakıcısıyla bir arada iken takip amaçlı bir cihaz kullandığını belirtirken, \% 97,7’si böyle bir cihaz kullanmadığını ifade etmiştir.

Ailelerin bakıcıları kontrol amaçlı olarak hangi sıklıkla aradıklarına ilişkin bulgular Tablo 16'da yer almaktadır.

Tablo 16. Ailelerin çocukları bakıcıyla beraberken hangi sıklıkla aradıkları

\begin{tabular}{lrr}
\hline & $\mathrm{f}$ & $\%$ \\
\hline Yarım saatte bir & 2 & 0,9 \\
Saat başı & 5 & 2,3 \\
2 saatte bir & 44 & 20,2 \\
Hiç aramam & 25 & 11,5 \\
Gerektiğinde & 142 & 65,1 \\
& & 100,0 \\
\hline
\end{tabular}

Tablo 16'daki verilere göre, ailelerin \% 0,9'u çocukları bakıcıyla beraberken bakıcıları yarım saatte bir aradığını belirtirken, \% 2,3’ü her saat başında, \% 20,2'si 2 saatte bir, \% 11,5’i hiç aramadığını ve \% 65,1’i de gerektiğinde aradığını belirtmiştir.

Ailelerin bakıcılara vermiş oldukları ücrete ilişkin bilgiler Tablo 17'de verilmiştir.

Tablo 17. Bakıc1lara verilen ücret

\begin{tabular}{llrr}
\hline & & $\mathrm{f}$ & $\%$ \\
\hline 1.250 TL ve altında & 32 & 14,7 \\
2. $251-500$ TL & 55 & 25,3 \\
3. $501-750$ TL & 83 & 38,1 \\
4.751 ve üzeri TL & 48 & 22,0 \\
& & & 100,0 \\
\hline
\end{tabular}

Tablo 17'deki verilerden izleneceği üzere, ailelerin \% 14,7'si çocuklarının bakımını üstlenen bakıcılara bu hizmetlerinin karşılığı olarak 250 TL ve altında bir ücret öderken, \% 25,3’ü 251-500 TL arasinda, \% 38,1’i 501-750 TL arasında ve \% 22'si de 751 TL ve üzerinde bir bakım ücreti ödemektedir.

Bakıcılara ödenen ücretlerin ailelerin maddi olarak zorlama durumuna ilişkin bulgular Tablo 18'de yer almaktadır. 
Tablo 18. Bakıcılara ödenen ücretin aileleri maddi olarak zorlaması

\begin{tabular}{lrr}
\hline & $\mathrm{f}$ & $\%$ \\
\hline Evet & 81 & 37,1 \\
Haylr & 137 & 62,9 \\
& & 100,0 \\
\hline
\end{tabular}

Tablo 18'den izleneceği gibi, ailelerin \% 37,1’i çocuklarının bakıcılarına ödedikleri ücretin kendilerini ekonomik olarak zorladığını, \% 62,9’u ise zorlamadığını belirtmiştir.

Tablo 19'da bakıcı bulamama veya bakıcının işten ayrılması durumunda ebeveynlerden annelerin işten ayrılıp ayrılmadığına ilişkin bulgular bulunmaktadır.

Tablo 19. Bakıcı bulamama veya bakıcının ayrılması durumunda işten ayrılma durumu

\begin{tabular}{lrr}
\hline & $\mathrm{f}$ & $\%$ \\
\hline Evet & 44 & 20,2 \\
Haylr & 174 & 79,8 \\
& & $\mathbf{1 0 0 , 0}$ \\
\hline
\end{tabular}

Tablo 19'da bakıcı bulamama veya bakıcının ayrılması nedeniyle annelerin \%20,2'si işten ayrılmak durumunda kalırken, \% 79,8'i böyle bir durumla karşılaşmadıklarını belirtmişlerdir.

Bakıcı bulamama veya bakıcının ayrılması durumunda işten ayrılan annelerin işten ayrılma türüne ilişkin bilgiler Tablo 20'de verilmiştir.

Tablo 20. İşten ayrilma türü

\begin{tabular}{lrr}
\hline & $\mathrm{f}$ & $\%$ \\
\hline İzin alma & 40 & 99,1 \\
İşten çıma & 4 & 0,9 \\
& & 100,0 \\
\hline
\end{tabular}

Tablo 20'deki veriler incelendiğinde bakıcı bulamama veya bakıcını ayrılması durumunda kendi işinden ayrılmak durumunda olan annelerin \% 99,1’i yasal izin hakkını kullanarak işten geçici süre ayrılması söz konusu iken, \%0,9’u da işten tamamen çıkmak durumunda kalmıştır.

Araştırmaya katılan ailelerin bakıcılarından memnun olma durumu aşağıda Tablo 21'de yer almaktadır

Tablo 21. Ailelerin bakıc1lardan memnun olma durumu

\begin{tabular}{lrr}
\hline & $\mathrm{f}$ & $\%$ \\
\hline Evet & 210 & 96,3 \\
Hayir & 8 & 3,7 \\
& & 100,0 \\
\hline
\end{tabular}


Tablo 21'deki verilere göre, çocuklarının bakıcılarından memnun olduğunu ifada eden ailelerin oran1 $\% 96,3$ iken, memnun olmadığını ifade eden ailelerin oranı $\% 3,7$ dir.

Tablo 22'de ailelerin çocuklarının bakıcılarından neden memnun olduklarına ilişkin bulgulara yer almaktadır.

Tablo 22. Ailelerin çocuklarının bakıcılarından neden memnun oldukları

\begin{tabular}{|c|c|c|}
\hline & $\mathrm{f}$ & $\%$ \\
\hline Titiz olmas1 & 2 & 0,6 \\
\hline Güler yüzlü & 3 & 0,8 \\
\hline Zamaninda gelmesi & 3 & 0,8 \\
\hline Çocuğumun gelişiminde ilerleme olması & 3 & 0,8 , \\
\hline Ev işlerine yardımcı oluyor & 4 & 1,1 \\
\hline Gözüm arkada kalmiyor & 5 & 1,4 \\
\hline Beklentilerimi yerine getiriyor & 6 & 1,7 \\
\hline Tecrübeli & 6 & 1,7 \\
\hline Sempatik & 7 & 2,0 \\
\hline Eğitsel oyunlar oynatıyor & 8 & 2,3 \\
\hline Çocukların beslenmesine dikkat ediyor & 8 & 2,3 \\
\hline Çocuklarıma iyi davranıyor & 10 & 2,8 \\
\hline Tanıdık olması & 10 & 2,8 \\
\hline Dürüst, samimi olması & 10 & 2,8 \\
\hline Eğitimli olması & 12 & 3,4 \\
\hline Çocuklarım bakıcısını görünce yüzü gülüyor & 15 & 4,2 \\
\hline İstediğim ölçütlere uyuyor & 15 & 4,2 \\
\hline Temiz & 16 & 4,5 \\
\hline İşini iyi yapıyor & 16 & 4,5 \\
\hline Çocuğumla iyi anlaşıyor & 21 & 5,9 \\
\hline Çocuklarımı sevmesi & 23 & 6,5 \\
\hline Çocuklar mutlu & 32 & 9,0 \\
\hline Güvenilir & 34 & 9,6 \\
\hline Çocuğumla ilgileniyor & 69 & 19,5 \\
\hline \multirow[t]{2}{*}{ Diğer } & 10 & 2,8 \\
\hline & & 100,0 \\
\hline
\end{tabular}

Tablo 22'deki bilgilere göre, araştırmaya katılan ailelerin bakıcılarından memnun olmalarının nedenlerin başında bakıcının çocuklarla ilgilenmesi (\%19,5), bakıcının güvenilir olması $(\% 9,6)$ ve bakıcının çocukları sevmesi (\%9) yer almaktadır.

Tablo 23'te bakıcılarından memnun olmayan ailelerin bunun nedenlerine ilişkin görüşlerine yönelik bulgular sunulmuştur.

Tablo 23. Ailelerin bakıcilardan neden memnun olmadikları

\begin{tabular}{|c|c|c|}
\hline & $\mathrm{f}$ & $\%$ \\
\hline Çocuğu tehdit etmesi & 1 & 3,3 \\
\hline Çocukla çok ilgilenmemesi & 1 & 3,3 \\
\hline Sürekli çocuktan yakınması & 1 & 3,3 \\
\hline Sabirli olmamas1 & 1 & 3,3 \\
\hline Aile işlerine karışması & 1 & 3,3 \\
\hline Eğitim düzeyinin düşük olması & 1 & 3,3 \\
\hline
\end{tabular}


Eğitici oyunlar oynamaması

Tablo 23’teki bilgilerden de anlaşılacağı üzere, ailelerin bakıcılardan memnun olmama nedenleri ilk sırada bakıcıların zamanında işe gelmemesi $(\% 26,7)$ almaktadır. Söz konusu bu nedeni bakıcının çocuğa yaklaşım tarzı $(\% 16,7)$ ve çocuğa düzenli yemek yedirmemesi $(\% 13,3)$ izlemektedir.

Ailelerin bakıcılarıyla sorun yaşama durumlarına ilişkin bulgular Tablo 24’te verilmiştir.

Tablo 24. Ailelerin bakıcılarla sorun yaşama durumu

\begin{tabular}{lrr}
\hline & $\mathrm{f}$ & $\%$ \\
\hline Evet & 16 & 7,3 \\
Haylr & 202 & 92,7 \\
& & 100,0 \\
\hline
\end{tabular}

Tablo 24'teki veriler incelendiğinde, araştırmaya katılan ailelerin \%92,7'si bakıcılarıyla herhangi bir sorun yaşamadıklarını belirtirken, \% 7,3’ü sorun yaşadıklarını ifade etmişlerdir.

Tablo 25’te ailelerin bakıcılarıyla yaşadıkları sorunlara ilişkin bulgulara yer almaktadır.

Tablo 25. Ailelerin bakıcılarıyla yaşadıkları sorunlar

\begin{tabular}{lrr}
\hline & $\mathrm{f}$ & $\%$ \\
\hline Kendine kolay gelen etkinliği yapması & 5,9 \\
İstenilen yemeği yapmaması & 5,9 \\
Çocuğa yemek yapmaması & 1 & 5,9 \\
Çocuğun uyumasını beklemesi & 1 & 5,9 \\
Çocuğa bakarken el iş yapması & 1 & 5,9 \\
Maddi olarak & 1 & 5,9 \\
İletişim sorunları & 1 & 5,9 \\
Güven sorunu & 1 & 5,9 \\
Bakıcının kendi sağlık sorunları & 1 & 5,9 \\
Bakıcının eşinin sağlık sorunları & 1 & 5,9 \\
Illgi ve bakım sorunları & 1 & 5,9 \\
Zamanında işe gelmemesi & 1 & 35,3 \\
& 6 & 100,0 \\
\hline
\end{tabular}

Tablo 25'teki bilgilerden ailelerin bakıcılarıyla yaşadığı sorunların en başında bakıcının zamanında işe gelememesi $(\% 35,3)$ olduğu anlaşılmaktadır. Bunun dışında aileler bakıcılarıyla; bakıcının kendine kolay etkinlikleri yapmayı tercih etmesi, istenilen yemeği yapmak istememesi, çocuğa yemek yapmaması, çocuğun bir an uyumasını beklemesi, çocuğa bakarken aynı anda da el işi yapması vb. sorunlar yaşadıkları gözlenmektedir. 
Ailelerin şu andaki bakıcılarıyla ne kadar süreyle devam etmeyi planladıklarına ilişkin bulgular Tablo 26'da verilmiştir.

Tablo 26. Ailelerin şu andaki bakıcılarıyla ne kadar devam etmeyi planladıkları

\begin{tabular}{lrr} 
& $\mathrm{f}$ & $\%$ \\
\hline Hemen değiştirmeyi düşününyorum & 2 & 0,9 \\
Çocuğum okula başlayana kadar devam edeceğim & 201 & 92,2 \\
Yeni bakıcı bulunca değiștireceğim & 1 & 0,5 \\
Ücreti yükselince değiştireceğim & 14 & 6,4 \\
& & 100,0 \\
\hline
\end{tabular}

Tablo 26'da göre, araştırmaya katılan ailelerin \%92,2'si çocukları okula başlayana kadar şu andaki mevcut bakıcıları devam etmeyi düşünürken, $\%$ 0,9’u hemen değiştirmeyi düşündügünü, $\% 0,5 ’ i$ yeni bakıcı bulunca değiştireceğini ve \% 6,4’ü de bakıcının ücreti yükselince değisstireceğini ifade etmiştir.

Ailelerin bakıcının rahatsızlanması veya acil durumları olduğunda çocuklarının bakımını kimin üstlendiğine ilişkin bulgular Tablo 27'de verilmiştir.

Tablo 27. Bakıcıların işe gelmediği durumlarda çocuklarının bakımını kimin üstlendiği

\begin{tabular}{lrr}
\hline & $\mathrm{f}$ & $\%$ \\
\hline Ben izin alıyorum & 86 & 39,4 \\
Eşim izin allyor & 46 & 21,1 \\
Kendi işyerime götürüyorum & 27 & 12,4 \\
Eşim işyerine götürüyor & 10 & 4,6 \\
Komşular bakıłyor & 8 & 3,7 \\
Akrabalar bakıyor & 41 & 18,8 \\
& & 100,0 \\
\hline
\end{tabular}

Tablo 27'deki veriler göz önünde bulundurulduğunda, ailelerin \%39,4’ü bakıcıların rahatsızlanmas1 veya acil bir durum nedeniyle işe gelememesi söz konusu olduğunda kendisinin izin aldığını, \%21,1’i eşinin izin aldığını, \% 12,4'ü kendi iş yerine götürdüğünü, \%4,6’s1 eşinin kendi işyerine götürdüğ̈̈nü, \%3,7’si komşularının baktığını ve \%18,8'i de akrabalarının baktığını belirtmiştir.

\section{SONUÇ VE TARTIŞMA}

Araştırmada, ailelerin EÇBE döneminde evde ücretli bakım hizmetlerine yönelik talepleri üzerinde belirleyici olan nedenlerin ve bu süreçte karşılaşılan sorunların ortaya konulması amaçlanmıştır. Ailelerin evde ücretli bakım hizmetlerine talepte bulunmaları üzerinde belirleyici olan nedenler arasında; ebeveynlerin eğitim düzeyi, ebeveynlerin çalışıyor olması, çocuğa bakacak başka kimsenin olmamasının yanı sıra çocuğun yaşının küçük olması yer almaktadır. Bakıcıların güvenilir olması ailelerin bakıcılarda aradıkları özelliklerin en başında gelmektedir. Bakıcılardan yalnızca çocuğa 
bakmaları değil, eğitsel faaliyetlerde bulunması ve ev içi işlere yardımcı olmaları da beklenmektedir. Genel olarak, ailelerin bakıcılarından memnun oldukları ve onlarla çocukları okula başlayana kadar devam etmeyi planladıkları görülmüştür. Bakıcıların zamanında işe gelmemesi aileler ile bakıcılar arasında yaşanan en önemli sorundur.

Araştırmada EÇBE döneminde evde ücretli bakım hizmetini talep eden ailelerden gerek annelerin gerekse babaların beşte dördünden daha fazlasının yükseköğretim/lisansüstü eğime sahip olduğu görülmektedir. Bu bulgu, eğitim düzeyi yüksek olan ailelerin evde ücretli bakım hizmetlerine daha fazla talep gösterdikleri biçiminde yorumlanabilir. Bu bulgu, konu ile ilgili yapılmış önceki çalışmaların sonuçları ile paralellik göstermektedir. Örneğin, King ve Hill (1993), eğitim düzeyi yüksek olan ailelerin daha ileri görüşlü olduklarını, çocuklarına ve onların eğitimine daha fazla önem verdiklerini belirtmektedir. Kakıcı, Emeç, ve Üçdoğruk’un (2007) araştırmalarında, eğitim düzeyi yüksek olan çalışan kadınların; ücretli bakım hizmetlerini daha fazla tercih etmiş olmalarının belirlenmiş olması, burada yapılan belirlemeyi güçlendirmektedir. Carlin ve diğerleri (2019) tarafından yapılan araştırmada da çalışan kadınlardan eğitim düzeyi yüksek olanların evde ücretli bakım hizmetlerini daha fazla tercih ettikleri gözlenmiştir.

Annenin/kadının çalışıyor olmasını hane üzerindeki etkisi, iki farklı bir biçimde gözlenmektedir. Bunlardan ilki, hane halkının tasarruf davranışında doğrudan etkide bulunmasıdır. Tahmin edileceği gibi, kadının işgücüne katılması hanede ek gelir miktarını artırır. Bu konuda yapılan çalışmalar Orta Doğu ve Afrika'daki bazı ülkelerde kadınların işgücüne katılmasının hane halkı gelirini \%25’e kadar artırabileceğini göstermektedir. Örneğin, Rio de Janeiro'da çocuk sahibi kadınların işgücü piyasasına girmesi aile gelirini \%16 oranında artırmıştır (De Barros ve diğerleri, 2013). Dolayısıyla, hanedeki bu gelir artışına bağlı olarak ailenin hem harcama miktarı hem de tasarruf miktarı da artırmıs olmaktadır (Dünya Bankası, 2009; Gürsel, Uysal ve Acar, 2011). Kadının işgücüne katılmasının hanedeki diğer bir etkisi ise dolaylı etkidir. Bu etki birçok farklı yoldan zincirleme şeklinde gelişmektedir. Yapılan çalışmalar, çalışan kadınların doğurganlık ve çocuk ölüm oranının düştüğünü, ailenin mevcut ölçekte sağlık ve eğitime daha büyük pay ayırabildiğini göstermektedir. Bunun yanı sıra, çalışan kadınların harcama davranışları da erkeklere göre farklılık göstermektedir (Dünya Bankas1, 2009; Gürsel, Uysal ve Acar, 2011). Erkekler elde ettikleri geliri göreli olarak eğlence, alkol, sigara gibi tüketimlere harcarken, kadınlar ise göreli olarak çocukların eğitimine ve sağlığına harcamaktadır. Yani, kadınların çalışıyor olması, ailelerin çocuklarının sağlık ve eğitimlerine daha fazla harcama yapılarak, onların insan sermayelerinin artırılması anlamına gelmektedir (Gürsel, Uysal ve Acar, 2011). Burada tekrar araştırmaya dönüldügünnde, araştırmaya katılan ailelerde annelerin hemen hemen tamamına yakın bir kısmının çalışıor olması, bu ailelerin 
evde ücretli bakım hizmetlerine olan taleplerinde belirleyici olduğu söylenebilir. Kakıcı, Emeç ve Üçdoğruk'un (2007) ilgili araştırmalarında, ebeveynlerden sadece babanın çalışması durumunda çocuklara daha çok annelerin baktığını, ebeveynlerden her ikisi ile sadece kadının çalıştığı tek ebeveynli ailelerde ise ücretli bakımın tercih edildiğini ortaya çıkardığı bulgusu da yapılan bu belirlemeyi doğrulamaktadır. Bunun yanı sıra, araştırmaya katılan ailelerin beşte birinin tek ebeveynli ailelerden oluşması ve çocukların anneleriyle birlikte kalıyor olması da yine yukarıda yapılan açıklamalarla örtüşmektedir. Yine, Dünya Bankası'nın (2015) çalışmasında da tam zamanlı çalışan kadınların \%8'inin evde ücretli bakım hizmetine başvurdukları belirtilmektedir.

Ailelerin evde bakıcı hizmetlerine talepte bulunmalarının öncelikli nedenleri arasında; anne-babanın çalışıyor olması, çocuğun yaşının küçük olması ve bakacak kimsenin olmaması yer almaktadır. Daha önce de belirtildiği gibi ebeveynler çocuk sahibi olduklannda çocuk bakımı ve çalışma ile ilgili bir seçim yapmak durumundadır. Bu noktada üzerinde duracakları ilk seçenek kendileri olmakta, bu olmadığında ise yakın çevrelerinden destek alma yoluna gitmektedirler. Diğer üçüncü seçenek ise kurumsal bakım hizmetinden yararlanmaktır. Ancak, ailelerin ilk üç seçeneğin bu konuyla ilgili sorunlarına yanıt vermesi durumunda, dördüncü ve sonuncu seçenek olan evde bakım hizmetlerine başvurmak durumunda kalabilmektedirler. Araştırmada ailelerin evde bakım hizmetine başvurmaları üzerinde en temel belirleyici nedenin; çocuğun yaşının küçük olması olduğu gözlenmiştir. Araştırmaya katılan ailelerin yarısından fazlasının 0-12 ay arasındaki çocuklarını bakıcıya vermiş oldukları ve bu oranın çocukların yaşları büyüdükçe azalmış olması da yapılan belirlemeyi güçlendirmektedir. Burada ulaşılan bu bulgunun alayazında yapılan çalışmalarla örtüştüğü gözlenmektedir (Ceylan, 2019; Tokuç ve Tuğrul, 2007; Tokuç 2007). Ceylan'ın ilgili araştırmasında, ailelerin çocuklarının yaşları büyüdükçe gelişimlerinin ve eğitimlerinin desteklenmesi amacıyla evde özel bakım hizmetinden ziyade, kurumsal bakım hizmetini tercih ettikleri gözlenmiştir. Tokuç ve Tuğrul'un (2007) araştırma bulgusu ebeveynlerin bu yöndeki eğilimlerinin eğitim düzeyi ilişkili olduğunu göstermektedir. Buna göre, ebeveynlerin eğitim düzeyi artıkça çocuklarının eğitim ve bakımı için kurum temelli EÇBE hizmetlerinden faydalanmaya yönelik eğilimleri daha küçük yaş gruplanına indiği ortaya çıkmıştır. Tokuç’un (2007) diğer çalışmasında, çalışan kadınların evde çalışan kadınlarla karşılaştırıldığında çocuklarını daha erken yaşlarda EÇBE kurumlarına gönderme eğiliminde oldukları gözlenmiştir.

Evde ücretli bakım hizmeti veren kadınların işyeri kendi işverenlerinin özel alanıdır. Söz konusu bu durum ücretli bakım hizmeti veren kadınları özel (ev) ile iş (kamu) arasında iki arada bir derede bırakır. Üstelik yapılan işin doğası gereği diğer işlerden farklı olarak, ücretli bakım hizmeti veren kadınların çalışma alanı yanında çalıştıkları ailelerin özel yaşamlarıyla iç içedir. Bütün bunlar 
nedeniyle, evde ücretli bakım hizmetlerine talepte bulunan aileler, bakıcıların birtakım özelliklere sahip olmalarını ön planda tutarlar (Özyeğin, 2014). Brydon ve Chant (1998 akt. Dikmen ve Kart, 2017) evde ücretli bakım hizmetleri için erkek çalışanlara yönelik bir talebin olmadığını, bu nedenle çalışan kadınların yalnızca "güvenilebilecek" bir hemcinsine evini, çocuklarını vb. emanet ederek hizmet almayı uygun bulduklarını belirtmektedir. Konuya buradan devam edildiğinde, mevcut araştırmaya katılan ailelerin de bakıcılarda aradıkları özellikler arasında ilk sırada bakıcının güvenilir olması gelmektedir. Yine, araştırmada elde edilen bulgulardan biri de yaklaşık her 10 ailenin dokuzunda çocukların bakıcılarıyla beş saat ve üzerinde bir arada bulunmasıdır. Her iki araştırma bulgusu birlikte değerlendirildiğinde, ailelerin hem çocuklarını hem de evlerini neden güvenilir bir hemcinsine emanet etmek istedikleri daha iyi anlaşılabilir.

Ailelerin bakıcıları işe almada ilk tercihleri bakıcının "tanıdık" olmasıdır. Bakıcının tanıdık olması, ailelerin bu bakıcılara rahatlıkla güvenebilmesine ve onlara her hangi bir kuşku duymadan itimat edebilmesine olanak tanımaktadır. Ailelerin tanıdıkları kişileri öncelikli olarak bakıcı olarak tercih etmelerinin nedenlerinden birinin de tanımadıkları kişileri bakıcı olarak tercih etme durumunda karşılaşacakları olası riskleri, tamamen ortadan kaldırmak istemeleri olduğu söylenebilir. Alanyazında yapılan araştırma bulguları da burada ulaşılan bulguları doğrulamaktadır (Dikmen ve Kart, 2017; Fidan ve Özdemir, 2011). Örneğin, Dikmen ve Kart'ın (2017) çalışmasında çocuk bakıcısı kadınların tamamına yakın bir kısmı, akraba-komşu-mahalleli olarak tanımlanan biçimsel olmayan ilişkisine bağlı olarak işe alınmışlardır.

Araştırmada ailelerin bakıcıları işe alma sürecindeki ikinci en iyi tercih etme nedeninin "referans" olduğu görülmektedir. Bunun nedeni, ailelerin kendileri için uygun bakıcıya daha kısa sürede ve maliyetle ulaşmayı düşünmüş olmaları olabilir. Koyuncu (2018) ailelerin referansa başvurmalarının arkasında daha önce hiç tanımadıkları insanları, ev içerisinde tanıma bakımından karşılaşacakları olası risk durumlarını en aza indirmek istemelerinin yer aldığını belirtmektedir. Bu doğrultuda, bu kişilerin yanında çalışmış olduğu diğer kişilerle iletişim kurulmaktadır. Referansı talep eden kişilerin diğer kişilerle iletişime geçme kanalları yüz yüze görüşme, telefonla görüşme ya da mektupla bilgi isteme biçiminde olabilmektedir (Bingöl, 1998). Söz konusu bu referans sahibi kişilerin toplumsal statüleri de verdikleri olumlu geri bildirimler kadar önemlidir. Öyle ki toplum içerisinde toplumsal statüsü yüksek ve sınıflı yapıda ayrıcalıklı bir konuma sahip ailelerin bu geri bildirimleri daha fazla kabul görmektedir (Koyuncu, 2018).

Çocuk yuvası, sevgi evleri ve çocuk evleri gibi resmi kurumlarda çalışan bakıcı annelerin/bakıcı kadınların görev tanımları bellidir. Bu kadınlara görevleri dışında ek bir görev verilmemektedir 
(Yaman, 2010). Resmi kurumlarda çalışan kadınların aksine, evde bakım hizmeti sunan kadınların ne iş yapacakları ve ne kadar çalışacaklarına ilişkin resmi bir iş tanımı yoktur. Üstelik bu kişiler bir iş sözleşmesinden de yoksundurlar. Dolayısıyla, belirtilen her iki durumda da işveren konumunda olan ailelerin bakıcılardan daha önceden belirtilmeyen başka işler yapmalarını talep etmelerine yol açabilmektedir (Dikmen ve Kart, 2017). Aslında, bu ilk başta olan bir şey değildir. Bakım hizmeti sunan kadınlarla aileler arasında başlangıçta resmi olan ilişkilerin zamanla yerini samimiyet, yakınlık ve aileden birisi olma gibi ataerkil bir yapıya bırakmasıyla olabilmektedir (Suğur, Suğur, ve Şavran, 2008). Bu ataerkil yapı, aileler ve bakıcılar arasındaki genel işçi-işveren ilişkisini kişiselleştirmekte ve bu ilişkiye ailevi bir nitelik kazandırmaktadır. Söz konusu bu yapı ailelere evde bakım hizmetinin iş tanımını çok geniş tutmasına ve uygulamasına neden olabilmektedir (Erdoğdu ve Tokgöz, 2013; Suğur, Suğur ve Şavran, 2008). Bütün bunların sonucunda, işverenler; bakıcılara başta sözlü olarak yapılan anlaşmaya dahil olmayan başka işler de yaptırma hakkını kendilerinde görebilmektedirler (Suğur, Suğur, ve Şavran, 2008). Araştırmaya katılan ailelerin çocuklarının bakıcılarından; çocuğa öğle yemeği hazırlama, ortalığı düzenleme, ütü gibi bir takım ek görevler yapmalarını talep etmeleri belirtilen bu ataerkil yapıyla açıklanabilir. Dikmen ve Kart'ın (2017) çalışmasında da araştırmaya katılan yaklaşık her iki çocuk bakıcısı kadından biri bakım hizmeti verdiği evde aynı zamanda temizlik ve yemek gibi ek işler de yapmış olduklarını belirmişlerdir. Fidan ve Özdemir'in (2011) ilgili çalışmasında da ev hizmetlerinde çalışan kadınlardan işe girişte belirtilen işlerin dışında işler istenildiği gözlenmiştir.

Araştırmadan elde edilen bulgular, ailelerin beşte birinden biraz fazlasının bakıcı bulamama veya bakıcının işi bırakması durumunda işten ayrılma sorunu ile karşı karşıya kaldığını göstermektedir. Ancak, bu işten ayrılma nedeni ise doğum sonrası ya da ylllık resmi izinleri kullanma olarak görünmektedir. İşten çıkma oranı ise yüzde birin altındadır. Bu durum, araştırmaya katılanların ağırlıklı olarak kamu hizmet alanında çalışıyor olmasıyla açıklanabilir. HÜNEE’nin (2014) araştırma sonuçlarına göre gebelik veya çocuk bakımı nedeniyle işten ayrılan kadınların oranı \%14'tür. Türkiye Kadın Girişimciler Derneği'nin (2015) ilgili araştırmasında da kadınların \%40’ının doğum sonrası işi bıraktığı tespit edilmiştir. Yine aynı araştırmada, işten ayrılma sürecinde asıl karar verici olanın kadınların kendilerinin olduğu ortaya konulmuştur.

Araştırmada, ailelerin çocuklarının bakımını üstlenen bakıcılarla yaşadıkları sorunların başında bakıcının zamanında işe gelmemesi olduğu belirlenmiştir. Araştırmaya katılan ailelerde ebeveynlerin tamamına yakın bir kısmının çalışıyor olduğu dikkate alındığında; ailelerin bunu öncelikli bir sorun olarak dile getirmelerinin anlaşılabilir olduğu söylenebilir. Bora (2014) kendisi de bir çalışan kadın olarak, bakım hizmeti sunan kadın çalışanın zamanında işe gelmemesi durumunu, 
bu süreçte yaşadığ1 önemli bir sorun olarak nitelemiştir. Diğer yandan, ailelerin bakıcılarla yaşadıkları sorunlardan biri de bakıcılara ödenen ücretle ilgilidir. Araştırmaya katılan yaklaşık her on aileden dördü bakıcılara ödedikleri ücretin kendi aile bütçelerini zorladığını ifade etmiştir. Fidan ve Özdemir'in (2011) araştırmasında ev hizmetlerinde çalışan kadınların iş seçerken evde çalışan/ev kadını olanları değil de çalışan kadınları tercih ettiklerini belirtmişlerdir. Bunun nedeni ilk grupta yer alan kadınlar işlerini yaparken onlara müdahale etmeleridir. İkinci grupta olan çalışan kadınların ise daha esnek olduğu ve onları işleri yaparken özerk bırakmalarıdır. Ancak, bu gruptaki kadınlar da ücret konusunda daha zorlayıcı olmaktadır. Dolayısıyla, ailelerin evde bakım hizmeti aldıkları kadınlarla ücret konusunda yaşadıkları sorunların bir kısmı yapılan bu açıklama çerçevesinde ele alınabilir.

Araştırmada üzerinde durulması gereken bulgulardan biri de ailelerin çocuklarının bakıcılarının rahatsızlanması veya acil/olağanüstü olarak değerlendirilebilecek bir durumla karşılaştığında işe gelemediğinde ne yaptıklarıdır. Bu konuda aileler dört farklı çözüm yoluna başvurmaktadır. Bunlardan ilki ebeveynlerin izin almasıdır. İkincisi, ebeveynlerin çocuğu işyerlerine götürmesidir. Üçüncüsü, ise çocuğa bir akrabalarının ve dördüncü ise bir komşularının bakmasıdır. Ancak, ortaya konulan bu çözüm yollarından ilk ikisi üzerinden devam edildiğinde çalışan kadınların eşlerinden destek görmelerine karşın, çocuğun bakım sorumluluğunun yine de kadınlar tarafından üstlenildiği söylenebilir. Araştırmaya katılan erkek ebeveynlerin bakıcının işe gelmemesi durumunda eşlerinin izin aldığını belirtmiş olması da burada yapılan belirlemeyi doğrulamaktadır. Dünya Bankası'nın (2015) daha önce belirtilen çalışmasında çalışan kadınların çalışmayan kadınlarla kıyasla evde çocuk bakımı ile ilgili görevlerde eşlerinden daha fazla destek aldığını ancak, çocuk bakım sorumluluğunda ağırlığın yine kadınlarda olduğu gözlenmiştir. AÇEV'in (2017) yakın zamanlarda yapmış olduğu araştırmada da çalışan kadınların eşlerinin ev içi işlerde ve çocuk bakımında daha çok sorumluluk aldıklarını ortaya koymaktadır. Ancak, çalışan kadınların eşleri her ne kadar bu konuda daha fazla sorumluluk üstlenmiş olsalar bile, yine de ataerkil bakış açısından tam olarak kendilerini kurtaramamışlardır.

Yukarıda yapılan açılamalar çerçevesinde EÇBE döneminde evde bakım hizmetlerinin arz boyutunu ele alan iki araştırma önerisinde bulunabilir. Bunlardan ilki çocuk bakım hizmeti veren kadınlara yönelik bir profil araştırmasıdır. İkincisi de yine bakım hizmeti veren kadınların işsüreci, çalışma koşulları, çocuk ve aile bireyleriyle yaşadıkları sorunları içeren bir çalışma yapılmasıdır.

\section{KAYNAKÇA}


Aassve, A., Arpino, B. ve Goisis, A. (2012). Grandparenting and mothers' labour force participation: A comparative analysis using the generations and gender survey. Demographic Research, 27, 53-84.

Anderson, P. M. ve Levine P. B. (1999). Child Care And Mothers' Employment Decisions. National Bureau Of Economic Research. Working Paper 7058. http://www.Nber.Org/Papers/W7058.

Anne Çocuk Eğitim Vakfi (2017). Türkiye’de ilgili babalık ve belirleyicileri. İstanbul: AÇEV

Arpino B., Pronzato C. ve Tavares L., (2012). Mothers' labour market participation: do grandparents make it easier? IZA Discussion Papper No. 7065.

Balc1, A. (2011). Sosyal bilimlerde arastırma (9. Bs.). Ankara: PEGEM A Yayınları

Baytar, B. D. (2014). Dil gelişimi sorunlarmın ortaya ģıkışında bakııının rolü (Yayınlanmamış yüksek lisans tezi). Maltepe Üniversitesi, İstanbul.

Beşpınar, F. U. (2016). Toplumsal cinsiyet ve aile. M. Truğut ve S. Feyzioğlu. Türkiye aile yapısı araştı́rması içinde (s. 234-279). Ankara: Aile ve Sosyal Politikalar Bakanlığı.

Bingöl, D. (1998). Insan kaynaklar yönetimi. (4. Bs). İstanbul: Beta Yayınları

Birleşmiş Milletler Çocuklara Yardım Fonu. (2013). Erken yaşlarda çocuk refahı ve kadın istihdamı. Ankara: UNICEF

Blau, D.M. ve Hagy A.P. (1998). The demand for quality in child care. Journal Of Political Economy, 106(1), 104-146.

Boğaziçi Üniversitesi Sosyal Politika Forumu (2009). Türkiye'de çocuk bakım hizmetlerinin yaygınlaştırılmasına yönelik bir öneri: Mahalle kreşleri. Erişim adresi: https://spf.boun.edu.tr/docs/MAHALLE\%20KRESLERI\%20\%20ARASTIRMA \%20RAPORU.pdf.

Bora, A. (2014). Kadinlar smıfı ücretli ev emeğg ve kadın öznelliğinin inşası (6. Bs). İstanbul: İletişim Yayınları.

Büyüköztürk, Ş., Çakmak, E. K., Akgün, Ö. E., Karadeniz, Ş. ve Demirel, F. (2013). Bilimsel araștırma yöntemleri. (15. Bs). Ankara: Pegem Akademi.

Carlin, C. , Davis, E. E., Krafft, C. ve Toutd, K. (2019). Parental preferences and patterns of child care use among low-income families: a bayesian analysis. Children and Youth Services Review, 99, 172-185.

Ceylan, R. (2019). Ebeveynlerin okul öncesi kurumu hakkındaki görüşleri: Tercih sebepleri, beklentileri ve memnuniyetleri. Elektronik Sosyal Bilimler Dergisi, 18 (70), 497-517.

Conti, G. ve Heckman, J. J. (2012). The Economics of child well-being. National Bureau of Economic Research Working Paper No. 18466. Erişim adresi: http://Www.Nber.Org/Papers/W1846.

Creswell, J. W. (2012). Educational research (4. Bs). NevYork, NY: Pearson. 
De Barros, R. P., Olinto, P., Lunde, T. ve Carvalho, M. (2013). The impact of access to free childcare on women's labor market outcomes: evidence from a randomized trial in low-income neighborhoods of Rio de Janeiro. Erişim adresi: http://documents.worldbank.org/curated/en/672391468231860498/pdf/814980BRI0Impa 00Box379810B00PUBLIC0.pdf.

Del Boca, D. (2015). The impact of child care costs and availability on mothers' labor supply. Erişim adresi: https://www.carloalberto.org/wp-content/uploads/2018/11/no.399.pdf.

Dikmen, A. A. ve Kart, M. E. (2017). Evde çocuk bakerm bizmetleri yoluyla kaynth kadm istibdammmn desteklenmesi operasyonu strateji belgesi. Erişim adresi: http://Www.Sgk.Gov.Tr/Yayinlar/StratejiBelgesi.Pdf.

Doğan, D. (2018). 0-12 ay grubundaki çocuklarm ebeveyn ve/ veya bakacularmm çocukları sevme ve avutma biçimleri. (Yayınlanmamış uzmanlık tezi). Trakya Üniversitesi, Edirne.

Doğan, N. (2013). Ölçme Araçlarının sinıflandırılması (6. Bs.). H. Atılgan (Ed). Eğitimde ölçme ve değerlendirme içinde (s. 119.144). Ankara: Anı Yayıncıllk.

Dünya Bankası (2009).Türkiye'de kadinlarn isgücüne katılımı: eğilimler, belirleyici faktörler ve politika çerçevesi. Washington DC: Uluslararası İmar ve Kalkınma Bankası.

Dünya Bankası (2015). Türkiye'de cocuk bakım bizmetlerinde arz ve talep durumu: bir karma yöntem çalısması. Washington DC: The World Bank.

Eğitim Reformu Girişimi ve Anne Çocuk Eğitim Vakfi (2016). Her Çocuğa Eşit Fırsat: Türkiye’de Erken Cocukluk Eğitiminin Durumu ve Öneriler. İstanbul: ERG ve AÇEV Yayını

Erdoğdu, S. ve Toksoz, G. (2013). Kadınlarn görünmeyen emeğinin görünen yü̈ü: Türkiye'de ev işşileri. Ankara: Uluslararası Çalışma Ofisi.

Fidan, F. ve Özdemir, M.Ç. (2011). Ev hizmetlerinde çalışan kadınlar ya da evlerin kadınları. Calıșma İlişkileri Dergisi, 2(1), 79-89.

Fraenkel, J. R. ve Wallen, N. E. (2009). How to design and evaluate research in Education (7. Bs) New York, NY: McGraw-Hill.

Gürsel, S., Uysal, G. ve Acar, A. (2011). Toplumsal değerler kadınların işgücüne katılmalarına engel. Erişim adresi: https://betam.bahcesehir.edu.tr/2011/05/toplumsal-degerlerkadinlarin-isgucune-katilmalarina-engel/

Hacettepe Üniversitesi Nüfus Etütleri Enstitüsü (2014). 2013 Türkiye nüfus ve sağhk araştırmas1. Ankara: Elma Teknik Basım Matbaacılık Ltd. Şti.

Ilkkaracan, I., Kim, K. ve Kaya, T. (2015). Sosyal bakem bizmetlerine kamu yatrrmlarmm istihdam, toplumsal cinsiyet eşitliği ve yoksulluğa etkileri: Türkiye örneği. İstanbul: İstanbul Teknik Üniversitesi, Bilim, Mühendislik ve Teknolojide Kadın Araştırmaları ve Uygulamaları Merkezi

Kağıtçıbaşı, C.., Sunar, D., Bekman, S. ve Cemalc1lar, Z. (2005). Erken müidahalenin erişkinlikte süren etkileri: Erken destek projesi’nin ikinci takip projesi'nin ön bulgular. İstanbul: AÇEV 
Kakıcı, H., Emeç, H. Ve Üçdoğruk, Ş. (2007). Türkiye'de çalışan kadınların çocuk bakım tercihleri. İstanbul Üniversitesi İktisat Fakültesi Ekonometri ve İstatistik Dergisi, 5, 20-40.

Kasnakoğlu, Z., Dayığlu, M. ve Erdil, E. (1997). Türkiye'de ev içi üretimin değeri. Türk-Iss Yullı̆ğ'97: 1990'larn bilançosu değerlendirme yažlar (2. Cilt). Ankara: Türk-İş Araştırma Merkezi. Ss. 185-199.

Kaytaz, M. (2005). Türkiye'de okul öncesi eğitiminin fayda-maliyet analizi. İstanbul: AÇEV.

Kızılgöl, Ö. A. (2012). Kadınların işgücüne katılımının belirleyicileri: Ekonometrik bir analiz. Doğus Üniversitesi Dergisi, 13 (1), 88-101.

King, E. M ve Hill, M. A. (1993). Women's Education in Developing Countries: Barriers, Benifits and Policies. Baltimore ve London: The Jhon Hopkins University.

Koyuncu, Ç. (2018). Evdeki yabancı: Ankara'daki Gürcü bakııı kadınlarn gündelik hayat mücadeleleri ve taktikleri (Yayınlanmamıs yüksek lisans tezi). Başkent Üniversitesi, Ankara.

Küçük, D. (2009). Bakıı tarafindan annesi tarafindan ve krește bakılan 3-6 yas çocuklarmn yasam kalitesi ve öz bakım becerilerinin değerlendirilmesi (Yayınlanmamıss yüksek lisans tezi). Atatürk Üniversitesi, Erzurum.

Organisation for Economic Co-Operation And Development [OECD] (2017). Starting strong 2017: key oecd indicators on early childhood education and care, Paris: OECD Publishing,

Özyeğin, G. (2014). Önsöz. Kadınlar simıfi Ücretli ev emeği ve kadin öznelliğinin inșası (6. Bs). İstanbul: İletişim Yayınları.

Paker, H. ve Uysal, G. (2016). Çocuklara kim bakıyor? Kadın işgücüne katılımı ve toplumsal cinsiyet. Erişim adresi: https://betam.bahcesehir.edu.tr/2016/12/cocuklara-kim-bakiyorkadin-isgucune-katilimi-ve-toplumsal-cinsiyet/

Pınarcıoğlu, N. Ş. ve Elçik, G. (2015). Kadınların kamusal hayata katıllmı açısından erken çocukluk bakerm ve eğitim hizmetlerinin önemi. Erken çocukluk bakerm ve eğitim paneli 20 Nisan 2015, İstanbul. İstanbul: KEİG Yayınları.

Sağlık- Sen Stratejik Araştırmalar Merkezi (2018). Kadın sağglı çalışanlarmmn iş ve aile hayatı uyumu araștırması. Ankara: Dekamat Ajans \& Matbaa.

Staab, S. ve Gerhard., R. (2010). Childcare Service expansion in chile and mexico for women or children or both? UNRISD Gender And Development Programme Paper No: 10 May, 2010.

Suğur, N., Suğur, S., ve Şavran, G.T. (2008): Türkiye'de orta sinıfin mazbut hizmetkarları: Kapıcılar, gündelikçiler ve çocuk bakıcıları. Siyasal Bilgiler Fakülte Dergisi, 63(3), 161-183.

Şavran, G. T. (2012). Nicel ve nitel araştırmalarda kullanılan araştırma teknikleri. T. G. Şavran (Ed.), Sosyolojide araştırma yöntem ve teknikleri içinde (s. 64-104). Eskişehir: Anadolu Üniversitesi Yayını Yayın No: 2641.

Tokuç, H. (2007). Anne ve babalarm okul öncesi eğitim bakkendaki görüss ve beklentilerinin incelenmesi (Yayınlanmamış yüksek lisan tezi). Hacettepe Üniversitesi, Ankara. 
Tokuç, H. ve Tuğrul, B. (Kasım, 2007). 1. Anne ve babalarn okul öncesi eğitim ile ilgili görüss ve beklentilerinin incelenmesi. Ulusal Ilköğretim Kongresi (15-17 Kasım 2017), Hacettepe Üniversitesi, Ankara.

Türkiye Kadın Girişimciler Derneği (2015). İyi ki annem çalışıyor. Erişim adresi: http://Www.Kagider.Org/Docs/Default-Source/Kagider-Raporlar/Kagider-Danone-$\% \mathrm{C} 3 \% \mathrm{~A} 7 \mathrm{al} \% \mathrm{C} 4 \% \mathrm{~B} 1 \% \mathrm{C} 5 \% 9 \mathrm{Fan}-$ Annelerin-i $\% \mathrm{C} 5 \% 9 \mathrm{Fe}-$ D $\%$ C3 $\%$ B 6 n $\%$ C3 $\%$ BC $\%$ C5 $\% 9 F \% C 3 \% B C-A r a \% C 5 \% 9 F t \% C 4 \% B 1$ rmaSonu $\%$ C3\%A7lar $\%$ C4\%B1.Pdf?Sfvrsn=2 Erişim Tarihi: 20.04 .2019

World Bank (2015a). Why Should We Care about Care? The Role of Childcare and Eldercare in Bosnia And Herzegovna. Washington DC: The World Bank.

World Bank (2015b). Why Should We Care about Care? The Role Of Childcare and Eldercare in Former Yugoslav Republic Of Macedonia. Washington DC: The World Bank.

World Bank (2016). Why Should We Care about Care? The Role of Childcare and Eldercare in Serbia. Washington DC: The World Bank.

Yaman, F. (2010). Bakıcı annelerin sosyo - ekonomik ve çalısma yaşamlarna ilişkin öz̧ellikleri: Ankara ili örneği (Yayınlanmamış yüksek lisans tezi). Hacettepe Üniversitesi, Ankara. 